\title{
Utazás előtti tanácsadás és betegedukáció a magyar utazóknál
}

\author{
Lengyel Ingrid ${ }^{1}$ - Felkai Péter dr. ${ }^{2}$ \\ ${ }^{1}$ Semmelweis Egyetem, Általános Orvostudományi Kar, Magatartástudományi Intézet, Budapest \\ ${ }^{2}$ Debreceni Egyetem, Orvos- és Egészségtudományi Kar, \\ Belgyógyászati Intézet, Utazásorvostani Tanszéki Csoport, Debrecen
}

\begin{abstract}
Bevezetés: Nemzetközi felmérések szerint az utazás során az utazók több mint fele valamilyen egészségi problémával találja magát szembe. Az utazási betegségek túlnyomó többsége utazás előtti orvosi tanácsadással megelőzhető, de a tanácsadás tematikájának és tartalmának meg kell felelnie az adott társadalom utazási szokásainak és utazási kultúrájának.

Célkitüzés: A jelen közlemény a magyar utazók és utazási szokások jellemzőit tárja fel.

Módszer: Egy utazási kiállitás résztvevői töltötték ki a nemzetközi utazásokra vonatkozó kérdőívet. A felmérés nem reprezentatív, az adatok csak egyszerú statisztikai módszerekkel voltak feldolgozhatók.

Eredmények: Az utazásorvostanban célszerú korcsoportfelosztás szerint a válaszadók 11\%-a fiatalkorú (15-24 év), 81\%-a felnőtt korú (25-59) és 8\%-a idősödő (60-74) korban volt. A válaszadók 28\%-a évente többször, 40\%-a évente, $32 \%$-a ritkán utazik. A felnőtt korú (16\%), a fiatalkorú (8\%) és az idősödő korú (4\%) válaszadók évente többször utazott.

Következtetések: A válaszok értékelése után megállapítható, hogy a magyar utazók úti céljai egy 13 évvel ezelőtti felméréshez képest szinte változatlanok: a válaszadó magyarok legtöbbje ( $95 \%$ felett) Európán belül utazott, a többiek más kontinenst kerestek fel. A magyarok általában nem endémiás területre utaznak, ezért utazás előtt tanácsadás céljából csak 5\%-uk keresi fel háziorvosát, 29\%-uk csak akkor, ha oltást kell felvenniük. Az utazni vágyók $42 \%$-a utazás előtt soha nem fordul a háziorvoshoz, noha a megkérdezettek $29 \%$-a tud valamilyen krónikus betegségéről. Az utazni vágyók $51 \%$-a az egészségügyi információkat tájékozódásul az internetról szerzi be, és csak 6\%-uk fordul orvoshoz. Mindez hangsúlyozza az utazás előtti tanácsadás szükségességét és a tanácsadás korszerú formáinak kidolgozását, a gyakorlatba való átültetésének szükségét.
\end{abstract}

Orv Hetil. 2018; 159(9): 357-362.

Kulcsszavak: betegedukáció, utazás előtti tanácsadás, utazásorvostan, betegjog, nemzetközi utazás

\section{Pre-travel advice and patient education of Hungarian travellers}

Introduction: According to international surveys, over half of the travellers face some kind of health issue when travelling. The overwhelming majority of travel-related illnesses can be prevented with pre-travel medical consultations, but the syllabus and content of the consultation have to match the travel habits and culture of the given society. Aim: This publication explores the specificities and travel habits of Hungarian travellers.

Method: One hundred participants of a travel exhibition completed a survey about their international travel. As the survey was not representative, the data could only be processed through simple statistical methods. However, since the exhibition was presumably attended by those wishing to travel, the conclusions drawn from the results are worth publishing, since no similar survey in Hungary has been published before.

Results: Based on the suitable classification of age groups in travel medicine, $11 \%$ of the participants were adolescents / young adults (aged 15-24), 81\% adults (25-59) and 8\% elderly (60-74). Twenty-eight percent of the participants travel multiple times a year, $40 \%$ yearly and $32 \%$ of them less frequently; $16 \%$ of the adults, $8 \%$ of the adolescents and $4 \%$ of the elderly age group travel multiple times a year.

Conclusions: The travel destinations of Hungarian travellers have remained practically unchanged since a study was conducted 13 years ago: the vast majority (95\%) travelled within Europe, $2 \%$ to the United States, and $11 \%$ of them elsewhere. Since Hungarians do not travel to endemic areas, only 5\% consulted their general practitioners (GPs) prior to travelling, and $29 \%$ did when they had to be vaccinated. Forty-two percent of those wishing to travel never consult their GPs, even though $29 \%$ of them are aware of some chronic illness. Instead, $51 \%$ gather their health information from the internet and only $6 \%$ from their doctors. By the contradiction between the poor health status of 
the majority of Hungarian travellers and the negligence of seeking pre-travel advice, our survey clearly points out the importance of the propagation of doctor's advice before trips, even if the travellers visit exclusively non-endemic countries like the European Union.

Keywords: patient education, pre-travel advice, travel medicine, patient's right, international travel

Lengyel I, Felkai P. [Pre-travel advice and patient education of Hungarian travellers]. Orv Hetil. 2018; 159(9): $357-362$.

(Beérkezett: 2017. november 3.; elfogadva: 2017. december 6.)

\section{Rövidítések}

$\mathrm{EU}=$ Európai Unió; VFR = (visiting friends and relatives) barátok, rokonok meglátogatása

Negyven év politikai eredetű utazási megszorításai után az 1980-as évek végén a magyar emberek előtt kinyílt a világ: semmiféle korlátozás nem állt a nemzetközi utazások útjába. A nyugati országokba és a tengerentúlra való látogatások száma megnőtt, ez elsőként a „bevásárlóturizmus" néven emlegetett jelenségnek volt köszönhető. A külföldre irányuló utazások számát a magyarok külföldi munkavállalásával kapcsolatos utak is szaporították, különösen 2004 után, amikor Magyarország csatlako- zott az Európai Unióhoz (EU). A külföldre utazók száma egy szintre állt be, és ezen csak a tartós munkavállalás céljából külföldre utazók száma változtatott valamicskét. A turistacélból tett látogatások száma pedig meglehetősen nagy ingadozást mutat, bár a terrorizmus elleni küzdelem jegyében meghozott repülőtéri megszorítások, illetve a gazdasági válság a magyarok külföldre való utazását nagyban befolyásolták (1. táblázat).

Ismeretes, hogy az utazók 49-59\%-a szembesül valamilyen egészségi problémával. A megbetegedettek 1826\%-a fordul orvoshoz, és 5\%-uk kerül kórházba külföldön [1, 2]. Egy USA-felmérés szerint minden 4000 beteg közül l igényelt hazaszállítást [3] - az európai biztosítók ennél gyakrabban folyamodnak a beteg haza-

1. táblázat | A nemzetközi utazások számának alakulása 1961 és 2016 között

\begin{tabular}{|c|c|c|c|c|c|}
\hline Év & Politikai esemény & $\begin{array}{l}\text { Összes külföldre } \\
\text { utazás (millió) }\end{array}$ & $\begin{array}{l}\text { Turistacélból } \\
\text { külföldre utazók } \\
\text { egynapos útjai } \\
\text { (millió) }\end{array}$ & $\begin{array}{l}\text { Turistacélból } \\
\text { külföldre utazók } \\
\text { többnapos útjai } \\
\text { (millió) }\end{array}$ & $\begin{array}{l}\text { Turistacélból tett } \\
\text { külföldi utazások } \\
\text { száma } \\
\text { (millió) }\end{array}$ \\
\hline 1961 & $\begin{array}{l}\text { A KEOKH szervezete a kémelhárításhoz kerül. } \\
\text { Egyszerűsödik az útlevélkérelem folyamata }\end{array}$ & 0,3 & Nincs adat & Nincs adat & Nincs adat \\
\hline 1972 & $\begin{array}{l}\text { Kék (világ-) és piros (szocialista) útlevelek forgalomba } \\
\text { hozatala }\end{array}$ & 1,4 & Nincs adat & Nincs adat & Nincs adat \\
\hline 1984 & Új útlevél forgalomba hozatala & 5,4 & Nincs adat & Nincs adat & Nincs adat \\
\hline 1988 & Világútlevél forgalomba hozatala & 10,8 & Nincs adat & Nincs adat & Nincs adat \\
\hline 1992 & Modern útlevél forgalomba hozatala & 12,8 & Nincs adat & Nincs adat & Nincs adat \\
\hline 1998 & Lézergravírozású útlevelek bevezetése & 12,3 & Nincs adat & Nincs adat & Nincs adat \\
\hline 2001 & A WTC elleni merénylet & 11,1 & Nincs adat & Nincs adat & Nincs adat \\
\hline 2002 & $\begin{array}{l}\text { A merénylet után a repülőtéri biztonsági intézkedések } \\
\text { megszorítása }\end{array}$ & 12,9 & Nincs adat & Nincs adat & Nincs adat \\
\hline 2004 & Magyarország csatlakozik az Európai Unióhoz & 16,9 & 1,9 & 6,7 & 8,6 \\
\hline 2005 & Vízum nélküli utazás Európában & 17,8 & 2,7 & 6,1 & 8,7 \\
\hline 2006 & A folyadékfelvitel tilalma a repülőgépre & 16,6 & 3,5 & 5,1 & 8,6 \\
\hline 2007 & Románia EU-csatlakozása & 17,3 & 3,5 & 5 & 8,5 \\
\hline 2008 & Magyarország csatlakozik a schengeni egyezményhez & 17,4 & 3,4 & 5,4 & 8,8 \\
\hline 2009 & Gazdasági világválság & 16,9 & 3,2 & 4,8 & 8 \\
\hline 2010 & Repülőtéri EU-s megszorító intézkedések & 16,3 & 3 & 4,6 & 7,6 \\
\hline 2013 & Horvátország EU-csatlakozása & 16 & 3,9 & 4,3 & 8,2 \\
\hline 2016 & Utolsó statisztikai adat & 18,9 & 3,9 & 6,3 & 10,2 \\
\hline
\end{tabular}


viteléhez. Az utazók 0,01-0,1\%-a szorul repatriációra, mert betegsége miatt nem tudja folytatni útját [4]. Sajnálatos módon az utazók csekély hányada megy el utazása előtt orvosi tanácsadásra, és arra is csak akkor, ha vakcinációt felvenni szükséges vagy tanácsos.

Röviden szólni kell az utazás előtti tanácsadásról: ennek jelentősége abban áll, hogy a magyar utazók igen kis hányada utazik endémiás területre, így nem szükséges számára védőoltás. Ebből következően nem fordul orvoshoz, ahol az utazási tanácsadás prevenciós triászából (vakcináció, kemoprofilaxis és betegedukáció) legalább az utóbbiban részesülhetne.

Az utazás előtti tanácsadás és a krónikus betegséggel utazók edukációja nyilvánvalóan az adott ország lakosainak utazási szokásait figyelembe véve lehet csak személyre szabott és hatásos. Minden populációnak megvannak a maga utazási szokásai, és az utazási tanácsadás szervezését, tartalmát és a prevenciós triász egyéb módszereit is ehhez szükséges igazítani. A megfelelő utazási tanácsadó rendszer múködtetéséhez, lakosságközelivé tételéhez szükséges megismernünk a magyar utazók utazási szokásait és az utazás előtti tanácsadáshoz való hozzáállásukat. Sajnálatos módon a magyar populáció utazási szokásait kevés közlemény vagy felmérés vizsgálta, és azok sem utazásorvostani közelítésből. Így felmérésünk célja a ma-

2. táblázat Életkori csoportok és jellemzőik az utazásorvostanban

\begin{tabular}{|c|c|c|}
\hline Életkori csoport & Év & Utazásorvostani jellemzók \\
\hline $\begin{array}{l}\text { Csecsemő- és } \\
\text { gyermekkor }\end{array}$ & $0-14$ & $\begin{array}{l}\text { Relatív magas veszélyeztetettség, az } \\
\text { utazással összefüggố megbetegedésekre } \\
\text { való reakció különbözik a felnőttekétől. } \\
\text { Mindig szülőii kísérettel/felügyelettel } \\
\text { utaznak. }\end{array}$ \\
\hline Fiatalok & $15-24$ & $\begin{array}{l}\text { Már gyakran utaznak egyedül, ritkábban } \\
\text { a szülőkkel. Általában még nem } \\
\text { alapítottak családot. Általában szerény } \\
\text { anyagi háttérrel rendelkeznek, } \\
\text { szerényebb szállásokat keresnek. } \\
\text { Hoszabb időtartamra utaznak, a helyi } \\
\text { lakossággal intenzívebb a kapcsolatuk. }\end{array}$ \\
\hline Felnőttek & $25-59$ & $\begin{array}{l}\text { Ök alkotják az utazók túlnyomó } \\
\text { többségét. Különböző desztinációkba } \\
\text { utaznak, sokféle utazási céllal, és } \\
\text { különböző minőségű elszállásolásra } \\
\text { tartanak igényt. }\end{array}$ \\
\hline Idősödő & $60-74$ & $\begin{array}{l}\text { Megnövekedett rizikófaktorú utazók, } \\
\text { általában már néhány krónikus } \\
\text { betegségben szenvednek, többségükben } \\
\text { nyugdíjasok. Kényelmes, minőségi } \\
\text { szállást és ellátást igényelnek. }\end{array}$ \\
\hline $\begin{array}{l}\text { Hajlott korú, } \\
\text { idős }\end{array}$ & $\begin{array}{l}75 \text { és } \\
\text { felette }\end{array}$ & $\begin{array}{l}\text { Magas rizikófaktorú utazók, általában } \\
\text { többszervi, általában egy vagy több } \\
\text { krónikus betegségben szenvednek. } \\
\text { Előtérbe kerülnek a geriátriai (belszervi, } \\
\text { mozgásszervi, lokomotoros és pszichés) } \\
\text { problémák. Speciális, gyakran körülmé- } \\
\text { nyes és rigolyás utazási szokásokkal és } \\
\text { habitussal rendelkeznek. Az elő- és } \\
\text { utószezonok tipikus utazói. }\end{array}$ \\
\hline
\end{tabular}

gyar emberek utazási szokásainak megismerése volt, közleményünkben pedig a kapott adatokból levonható utazásorvostani szempontú következtetéseket ismertetjük.

\section{Módszer}

A felmérés résztvevői egy tematikus utazási kiállítás nem szakmai napokon megjelenő látogatói voltak. A látogatók utazási szándéka feltételezhető volt, valószínúleg az utazási lehetőségek megismerése miatt látogattak el a kiállításra. A kívánt információkhoz való hozzájutást az önkitöltős feleletválasztós kérdőív megválaszolása szolgáltatta. A válaszadók alacsony száma $(\mathrm{n}=100)$ miatt reprezentatív felmérésről nem lehetett szó, ezért csak az egyszerü statisztikai módszerek adta eredményeket tudtuk értékelni. A korcsoportbeosztást az utazásorvostanban megfelelőnek talált családi életciklus beosztása alapján végeztük [5], azzal a megszorítással, hogy az egészen fiatal és egészen idős korosztályt nem szerepeltettük, mivel azok nem töltöttek ki kérdő́ivet. Mivel ez a fajta felosztás még nem szerepelt a magyar szakirodalomban, ezért szükségesnek látszik azt egy táblázat keretében röviden ismertetni (2. táblázat).

A kérdések az utazási szokások felmérésén kívül a kérdőívet kitöltők ismert betegsége(i)re, az esetleges rendszeres gyógyszerszedésre, az utazás előtti háziorvosi vagy egyéb orvosi konzultációra, valamint az útipatika ismeretére és annak összetételére vonatkoztak. Ezeken túl az utazás során elszenvedett betegségekről, a vakcinációról és az utasbiztosítással kapcsolatos ismereteikról is tájékozódtunk. A jelen közleményünkben a felmérés a nemzetközi utazásokkal kapcsolatos szokásokra és a magyar utazók úti céljaira, az utazás előtti tanácsadás igényére fókuszál, és ezeknek a témáknak a vonatkozó részeit vizsgáljuk.

\section{Eredmények}

A 100 válaszadó közül 86\% nő, 14\% férfi volt. A válaszadók korcsoportbeosztását a 3. táblázat mutatja.

Az utazás gyakorisága tekintetében $28 \%$ évente többször, $40 \%$ évente, $7 \%$ öt-tíz évente, az utazni szándékozók közül pedig 25\% ritkán hagyja el az országot. Mivel a ritkán utazás és az 5-10 évente való utazás gyakorlatilag redundáns fogalmak, az első két csoportot összevonva azt találjuk, hogy a vizsgált populáció (az utazás iránt érdeklődók) közel kétharmada évente legalább egyszer elhagyja az országot (1. ábra).

3. táblázat |A válaszadók megoszlása kor szerint $(\mathrm{n}=100)$

\begin{tabular}{lc}
\hline Az utazók kora & Az utazók száma \\
\hline Fiatalkorú (15-24) & 11 \\
Felnőtt korú $(25-59)$ & 81 \\
Idősödő $(60-74)$ & 8 \\
\hline
\end{tabular}




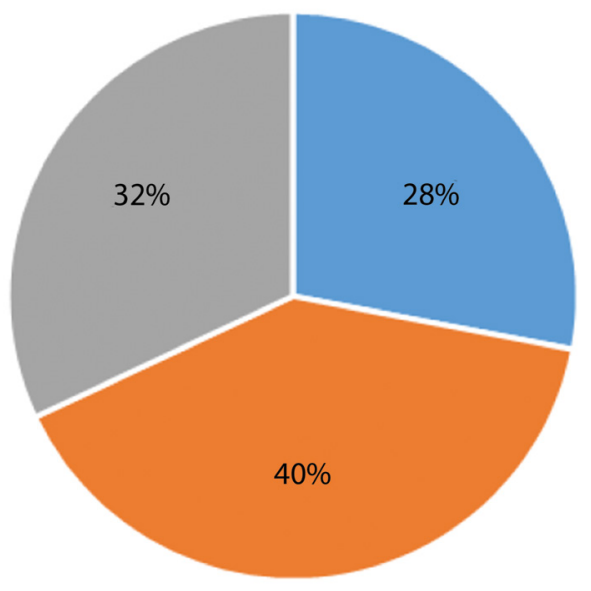

Évente többször EÉvente Ritkán

1. ábra $\quad$ A válaszadók utazási gyakorisága

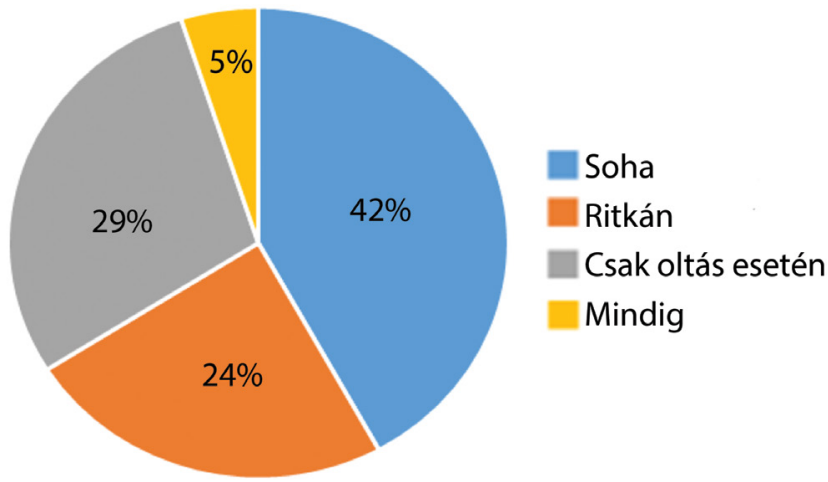

2. ábra

| A háziorvos nyújtotta, utazás előtti tanácsadás gyakorisága

A felmérésben az utazási gyakoriságot tovább vizsgálva, a korcsoportos megoszlás tekintetében a 4. táblázatban feltüntetett megoszlás tapasztalható.

Mivel a magyarok fóbb úti céljairól régebbi adatok is rendelkezésre állnak $[6,7]$, megvizsgáltuk, hogy 13 éves távlatban változtak-e a magyar utazók desztinációi [6]. Mivel az előző felmérések alapján feltehető volt, hogy a magyar utazók többsége még mindig Európán belül utazik, az európai úti cél tekintetében több tevékenységet is megjelölhettek a válaszadók, de emellett maradt a többi kontinensre felosztott úticél-megjelölés (5. táblázat). A kérdéseknél több úti cél is megjelölhető volt.
4. táblázat $\mid$ A válaszadók utazási gyakorisága korcsoportok szerint (\%)

\begin{tabular}{lccc}
\hline Az utazók kora & \multicolumn{3}{c}{ Az utazás gyakorisága } \\
\cline { 2 - 4 } & Évente többször & Évente & Ritkán \\
\hline Fiatalkorú (15-24) & 8 & 12 & 11 \\
Felnőtt korú (25-59) & 16 & 28 & 18 \\
Idősödő $(60-74)$ & 4 & - & 3 \\
\hline
\end{tabular}

A veszélyek ismeretének, azok megelőzésének egyetlen módja az utazás előtti egészségügyi tanácsadás, melyet a házi (gyermek)-orvostól, a gyógyszerésztől, vagy ha az illető endémiás területre utazik, az oltóközpont orvosától kaphat meg az utazó. Az utazó - fóleg a krónikus beteg utazó - egészségi állapotát jól ismerő háziorvos ideális lenne az utazás előtti tanácsadó személynek. Ezért az utazás előtti háziorvosi felkészítő konzultáció gyakoriságát és tényét külön kérdés mérte fel. Ennek eredményét a 2. ábra szemlélteti.

Krónikus betegség(ek)ben szenvedő embereknek - az idősödő korcsoportban egyre több ilyen van - az utazás előtt megfelelő előzetes orvosi tanácsadásban kellene részesülnie. Felmérésünk kitért arra is, hogy az utazni vágyók tisztában vannak-e saját egészségi állapotukkal. A megkérdezettek 29\%-a tud saját krónikus betegségéről. Bár a válaszadóknak ugyancsak a $29 \%$-a szed rendszeresen valamilyen gyógyszert, a rendszeres gyógyszerszedők közül csak 16\% jelezte, hogy a gyógyszereket valamilyen ismert idült betegségére szedi.

Az utazás előtti megfelelő felkészülés elengedhetetlen része a naprakész tájékozódás a célországban található egészségügyi viszonyokról, az utazó egészségét ott fenyegető veszélyekről. A kérdések egyik súlypontja az volt, hogy a válaszadó honnan szerzi be az utazás előtti, egészséggel és életmóddal összefüggő tanácsokat. Ennél a kérdésnél is több információforrás megjelölhető volt (6. táblázat).

\section{Megbeszélés}

Világszerte - így hazánkban is - a szabadidő eltöltésének leggyakoribb formája az utazás. Az utazási kedv növekedésével sajnálatos módon nem járt együtt az utazók az irányú igénye, hogy az utazás előtt tájékozódjanak az út alatti vagy a célország(ok)ban az egészségüket fenyegető

5. táblázat | Magyar utazók úti céljai 13 év távlatából. Az úti célok közül a válaszadók többet is megjelölhettek

\begin{tabular}{|c|c|c|c|c|c|c|c|c|}
\hline & $\begin{array}{l}\text { Európa, } \\
\text { városnézés }\end{array}$ & $\begin{array}{l}\text { Európa, } \\
\text { tengerpart }\end{array}$ & $\begin{array}{c}\text { Európa, } \\
\text { szabadidő, } \\
\text { sport }\end{array}$ & $\begin{array}{c}\text { Európa } \\
\text { összesen }\end{array}$ & Ázsia & Afrika & $\begin{array}{l}\text { (Dél- és } \\
\text { Észak-) } \\
\text { Amerika }\end{array}$ & Egyéb \\
\hline A szerzők felmérése szerint, 2017 & 55 & 47 & 4 & 106 & 2 & 0 & 2 & 9 \\
\hline A KSH 2004. évi felmérése szerint & $\mathrm{x}$ & $\mathrm{x}$ & $\mathrm{x}$ & 94,5 & 1,2 & 2,6 & 1,3 & 0,4 \\
\hline M.Á.S.T.-felmérés szerint, 2004 & $\mathrm{x}$ & 41 & $\mathrm{x}$ & 99 & $\mathrm{x}$ & $\mathrm{x}$ & 2 & 38 \\
\hline
\end{tabular}

$\mathrm{x}=$ nincs adat 
6. táblázat $\mid$ Az utazók információforrásai, összehasonlítva egy amerikai felmérés [17] adataival. Egy utazó több információforrást is meg nevezhetett

\begin{tabular}{lcc}
\hline Tanácsadó & $\begin{array}{c}\text { Az igénybe vevők } \\
\text { százaléka (USA) }\end{array}$ & $\begin{array}{c}\text { Az igénybe vevők } \\
\text { százaléka } \\
\text { (Magyarország) }\end{array}$ \\
\hline Barát, családtag & $30 \%$ & $14 \%$ \\
Háziorvos & $60 \%$ & $5 \%$ \\
Foglalkozás-egész- & $12 \%$ & Nincs adat \\
ségügyi orvos & $19 \%$ & $51 \%$ \\
Internet & $10 \%$ & $1 \%$ \\
Utazási orvos & Nincs adat & $20 \%$ \\
Gyógyszerész & Nincs adat & $9 \%$ \\
Egyik sem & & \\
\hline
\end{tabular}

veszélyekről. Az utazási betegségek megelőzése, így az utazásorvostani diszciplína fontos feladattá vált. A prevenció az ún. biomedicinális prevenciós triász (utazás előtti tanácsadás, védőoltások és kemoprofilaxis) alkalmazásával valósítható meg [8].

A válaszadók alkotta minta alapján - noha az utazással kapcsolatos rendezvény résztvevői alkották a válaszadókat - néhány megállapítást tehetünk a magyar emberek utazási szokásairól. Már ebben a kis mintában is észrevehető pár általános jellemző, főleg a desztinációk választása, az utazásra való felkészülés személyi felelőssége, az egészség és betegség ismerete, valamint az utazás idejére kiterjedő öngondoskodás vonatkozásában.

A megkérdezettek közül a felnőtt korú válaszadók voltak túlnyomó többségben (81\%), s ez az eredmény jól korrelál a családi életciklus utazásorvostanra adaptált megfigyelésével.

Az utazás gyakorisága tekintetében a megkérdezettek több mint fele évente legalább egyszer utazik külföldre, tehát az utazási tanácsadás az utazók többségénél, mint igény, felmerülhetne. Annál is inkább, mert a válaszadók korát vizsgálva mind a fiatalkorú, mind az idősödő korosztály - tehát a relatíve nagyobb kockázatú korcsoport - is évente több alkalommal utazik.

A Magyarországról külföldre utazók az EU-s felmérések szerint is az összes magyar utazónak csak a 27\%-át teszik ki [9], és ezeknek az utasoknak is túlnyomó többsége (94,5\%) Európán belül utazik [6]. A magyar utazók úti célja az elmúlt 13 év alatt sem változott sokat. A magyar utazók és a válaszadók is előnyben részesítik a tengerparti üdülést - ennek pedig kézenfekvő, legközelebbi célországa Horvátország, annál is inkább, mert az ország 2013-ban EU-tagállam lett, így az utazás még könnyebbé vált 2016-ban. A turisztikai célú (egy- vagy többnapos) külföldi utazások legfontosabb motivációja az üdülés volt $(48,1 \%$ említette), valamint a barátok, rokonok meglátogatása (visiting friends and relatives - VFR) $(36,7 \%)$. A harmadik leggyakrabban említett ok az üzleti út, illetve valamilyen kiállítás, vásár meglátogatása volt $(6,1 \%)$ [10]. Érdekességként meg kell említeni, hogy 2005-ben a második leggyakoribb utazási motiváció a bevásárlás volt (23\%), míg a VFR 16\%-ban szerepelt az utazás céljai között [11].

Az 5. táblázatból látható, hogy a magyar utazóknak csak kb. a 10\%-a utazik olyan területre, ahol a fertőző betegségek endémiás veszélyével kell számolni. Ezért nem meglepő, hogy az utazó - mivel utazás előtt rendszerint időhiányban szenved - nem megy el az időigényes orvosi tanácsadásra, hacsak nem szükséges védőoltást felvennie. Amíg a nem endémiás területre utazók esetében az utazás előtti tanácsadás kihagyása csak az érintett személy egészségére jelent veszélyt, addig a trópusi/szubtrópusi/endémiás területre való utazás előtti szaktanácsadás, gyógyszeres prevenció - pl. malária esetében [12] - és vakcináció elmaradása akár az utazó életet veszélyeztető megbetegedését, a vakcinációval megelőzhető fertőző betegség behurcolása pedig komoly közegészség- és járványügyi problémát okoz [13]. Még az idült betegségben szenvedő utazók sem fordulnak gyakrabban háziorvosukhoz, mint egészséges társaik [14]. Az utazás előtt orvosi tanácsot nem kérók száma egy USA-felmérés szerint 46\% volt [15]. Nincs ez másképp tehát a magyar utazóknál sem. Az utazási tanácsadásban, az utazók felkészítésében a háziorvosoknak meghatározó szerepük volna. Mivel a háziorvos az általa ellátott betegek anamnézisének, aktuális betegségének és gyógyszerelésének a legjobb ismerője, az utazó választása a jelen magyarországi helyzetben akkor lenne a legjobb, ha kérdéseivel, problémáival közvetlenül a háziorvosához fordulna [16]. Egyes egészségtudatos társadalmakban az utazók 60-65\%-a kér háziorvosától utazás előtti tanácsot $[17,18]$.

Mivel a célország egészségügyi viszonyairól való tájékozódást azért szükségesnek tartják az útra készülők, megpróbálnak naprakész információkat szerezni a meglátogatni szándékozott régiókról. Nem mindegy azonban, hogy a tájékoztatás forrása mennyire autentikus: a legtöbb utazni vágyó az internetet (51\%) és a családtagokat, barátokat $(14 \%)$ - tehát nem autentikus forrást - nevezte meg mint az utazás előtti egészségügyi tájékozódás forrását. Örömteli viszont, hogy a válaszadók 20\%-a gyógyszerészt kérdezett meg utazása előtt.

A magyar utazni vágyók egészségtudatos viselkedésének szomorú cáfolata az a tény, hogy miközben a válaszadóknak csak a 2\%-a vallja egészségesnek magát, egynegyedük nem tartja szükségesnek az utazás egészségére gyakorolt hatásáról való tájékozódást semmilyen forrásból. Sőt csak 5\%-uk megy el a háziorvosához utazás előtt. Sajnos nemzetközi téren sincs ez másképp: a háziorvoshoz csak azok a betegek mennek el, akik utazásukról betegen térnek vissza [19]. Ez a tény viszont hangsúlyozza az utazásorvostani tudásanyag beépítésének sürgető szükségét a háziorvosi képzésbe. További kutatás alapját képezheti az a szignifikáns eltérés, amely a $2 \%$ egészséges válaszadót, valamint azt a 71\% válaszadót állítja párhuzamba, akik azt vallották, hogy nincs ismert betegségük, közben pedig rendszeres gyógyszerszedők. 


\section{Következtetések}

Megállapíthatjuk tehát, hogy a magyar utazók utazási szokásai nem változtak jelentősen az eltelt bő 10 évben. Jellemző desztinációjuk Európa, jellemző tevékenységük a tengerparti nyaralás. Noha a megkérdezettek kb. 70\%-a legalább évi egy nemzetközi utazást tesz, sokuk nincs tisztában krónikus betegségével, vagy semmibe veszi azt, és csekély hányaduk fordul háziorvosához utazása előtt. Főbb egészségügyi ismeretforrásuk az internet, de örvendetes, hogy a gyógyszerészek egyre növekvő számban szerepelnek mint utazás előtti tanácsadást nyújtó hiteles személyek. A fenti eredmények megerősítik azt a feltevést, hogy az utazók többsége úgy véli, hogy Európában nem kell tartaniuk fertőző betegségektől, ezért a vakcináció is felesleges. Az oltást nyújtó orvost ezért nem keresik fel, így az egyéb profilaktikus lehetőségekról sem értesülnek. Mindez hangsúlyozza a megfelelő módon, lakosságközelbe hozott valid, utazás előtti tanácsadás szükségességét. Ennek szereplőit és formáit a szakembereknek kell kidolgozniuk és a döntéshozók elé terjeszteniük.

Anyagi támogatás: A közlemény megírása anyagi támogatásban nem részesült.

Szerzői munkamegosztás: L. I.: A felmérés végzése, az anyaggyưjités és az eredmények értékelése. F. P.: Irodalomkutatás és az eredmények interpretálása. A cikk végleges változatát mindkét szerző elolvasta és jóváhagyta.

Érdekeltségek: A szerzőknek nincsenek érdekeltségeik.

\section{Köszönetnyilvánítás}

A szerzők köszönetüket fejezik ki Domonkos Ágnesnek, a KSH Komplex Szolgáltatások Osztálya és Csomós Balázsnak, a Magyar Turisztikai Ügynökség munkatársának.

\section{Irodalom}

[1] Getz L, Larssen KE, Dahl B, et al. Health problems in Norwegians travelling to distant countries. Scand J Prim Health Care 1990; 8: 95-100.

[2] McIntosh IB, Reed JM, Power KG, et al. The impact of travel acquired illness on the world traveller and family doctor and the need for pre-travel health education. Scott Med J. 1994; 39: $40-44$.

[3] Wirtanen W. Statistics: Will I have a medical emergency overseas? Int Travel News 2011; 8: 58.

[4] Steffen R, Rickenbach M, Wilhelm U, et al. Health problems after travel to developing countries. J Infect Dis. 1987; 156: 84-91.

[5] Backer E. Investigating the family life cycle model in tourism. In: Schänzel H, Yeoman I, Backer E. (eds.) Family tourism, multi- disciplinary perspectives. Channel View Publications, Bristol, Buffalo, Toronto, 2012; p. 169.

[6] Characteristics of international travel and tourism demand 2004. [A nemzetközi idegenforgalom és turisztikai kereslet jellemzői 2004.] KSH-kiadvány, Budapest, 2005. [Hungarian]

[7] M.Á.S.T. Market and Public Opinion Poll Company. Travel practices of the Hungarian population, 2004. [M.Á.S.T. Piac- és Közvéleménykutató Társaság. A magyar lakosság utazási szokásai, 2004.] Turizmus Bulletin 2005; 1: 21-31. [Hungarian]

[8] Felkai P. Analysis of prevention in travellers diseases on the basis of latest results in travel medicine. [Az utazással összefüggő megbetegedések megelőzésének elemzése az utazási orvostan legújabb eredményei alapján.] Orv Hetil. 2008; 149: 1707-1712. [Hungarian]

[9] Bovagnet CL. How European go on holiday. Stat Focus 2006; 18: 2 .

[10] Hungarian Tourism Agency. National and international travel of the Hungarian population in 2016. [Magyar Turisztikai Ügynökség. A magyar lakosság belföldi és külföldi utazásai 2016ban.] Magyar Turisztikai Ügynökség, Budapest, 2017. Available from:http://szakmai.itthon.hu/documents/28123/4083489/ Helyzetelemzes_2017_0116.pdf/[accessed: December 1, 2017].

[11] Tourism in Hungary, 2005. [Turizmus Magyarországon, 2005.] Magyar Turizmus Zrt., Budapest, 2005. Available from: http:// itthon.hu/documents/28123/3629999/turstat2005_magyar_ vegleges $/ 2 \mathrm{dba} 4 \mathrm{~b} 90-733 \mathrm{e}-455 \mathrm{c}-8369-44 \mathrm{~d} 455 \mathrm{a} 3 \mathrm{~d} 882$ [accessed: August 13, 2017]. [Hungarian]

[12] Axmann A, Tuyet VT, Anh CK, et al. Problems of chloroquineresistant Plasmodium falciparum. Ther Hung. 1988; 36: 51-55.

[13] Vida J. The place of serology results in occupational healthcare. [Szerológiai eredmények helye a foglalkozás-egészségügyben. Fórum, 2017. szeptember 13.] Országos Közegészségügyi Intézet, Budapest. Available from: http://www.omfi.hu/letolt/ forum/05_Dr_Vida_Judit_(OMFI)_FESZ-forum_2017-0913_OKI-OMFI.pdf [accessed: December 1, 2017]. [Hungarian]

[14] Gagneux-Brunon A, Andrillat C, Fouilloux P. Pre-travel advice seeking from GPs by travellers with chronic illness seen at a travel clinic. J Travel Med. 2016; 23: pii: taw013; doi: 10.1093/ $\mathrm{jtm} / \mathrm{taw} 013$

[15] LaRocque RC, Rao SR, Tsibris A, et al. Pre-travel health adviceseeking behavior among US international travelers departing from Boston Logan International Airport. J Travel Med. 2010; 17: 387-391.

[16] Felkai P, Felkai E. Travel medicine in general practice. [Utazási orvostan a háziorvosi gyakorlatban.] Lege Artis Med. 2005; 15 : 632-641. [Hungarian]

[17] Hamer DH, Connor BA. Travel health knowledge, attitudes and practices among United States travelers. J Travel Med. 2004; 11 : 23-26.

[18] Walz A, Tschudi P, Badertscher N, et al. Pre-travel advice - a study among Swiss general practitioners. [Beratung vor der Reise - eine Umfrage bei Schweizer Hausärzten]. Ther Umsch. 2013; 70: 313-317. [German]

[19] Reed JM, McIntosh IB, Power K. Travel illness and the family practitioner: A retrospective assessment of travel-induced illness in general practice and the effect of a travel illness clinic. J Travel Med. 1994; 1: 192-198.

(Lengyel Ingrid, Budapest, Jókai u. 12., 1195 e-mail: lengyel.ingrid@gmail.com) 